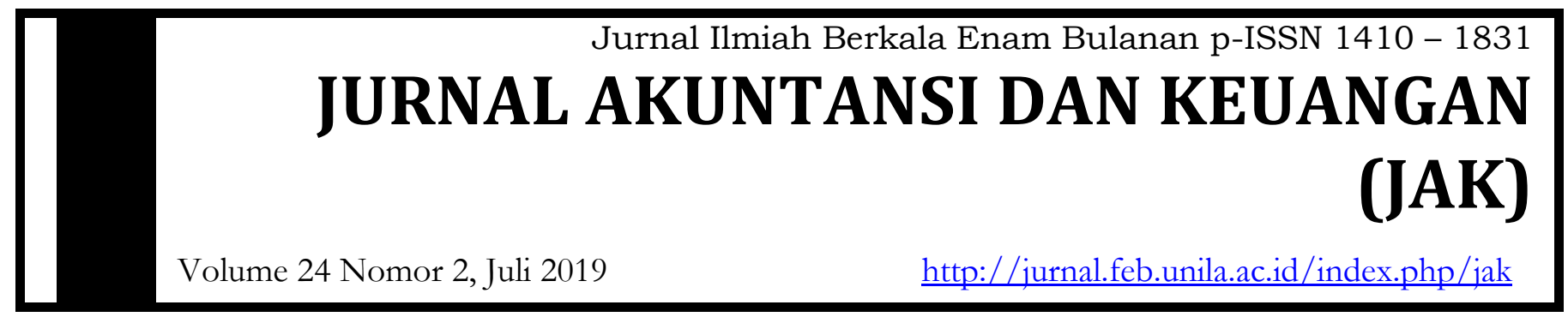

\title{
ANALISIS EFEK ANTESEDEN STRUKTUR MODAL PADA NILAI PERUSAHAAN
}

\section{Ruli Indriani', Ratna Septiyanti², Ninuk Dewi Kusumaningrum³ ${ }^{3}$, Usep Syaipudin}

1 Fakultas Ekonomi dan Bisnis Universitas Lampung

2 Fakultas Ekonomi dan Bisnis Universitas Lampung

${ }^{3}$ Fakultas Ekonomi dan Bisnis Universitas Lampung

${ }^{4}$ Fakultas Ekonomi dan Bisnis Universitas Lampung

\section{Informasi Naskah}

\section{Update Naskah:}

Dikumpulkan: 30 Mei 2019

Diterima: 30 Juni 2019

Terbit/Dicetak: 30 Juli 2019

\section{Keywords:}

Antecedent Effect, Capital Structure, Firm Value, Factor Analysis.

\section{$\underline{\text { Abstract }}$}

The research aims to examine the antecedent variables of capital structure, such as profitability, firm size, investment opportunity set, managerial ownership, and dividend policy, and its effect on the firm value. We used 41 listed firms of the Indonesia Stock Exchange from manufacturing industry in 2012-2017 period. We used factor analysis to determine the representativeness of independent variables as the capital structure variables then we tested its effect on firm value by using multiple linear regression. The results indicate that profitability, firm size, investment opportunity set, managerial ownership, and dividend policy simultaneously have a statistically significance influence on capital structure. Partially, profitability has a statistically significance negative effect on capital structure, investment opportunity set has a statistically significance positive effect on capital structure, and managerial ownership has a statistically significance negative effect on capital structure, while firm size and dividend policy have no statistically effect on capital structure. This research give an empirical evidence that capital structure have a statistically significance positive effect on firm value. This result have an implication that the antecedent effect of capital structure is positive and statistically significance on firm value. 


\section{A. PENDAHULUAN}

Perkembangan zaman yang semakin maju membuat perusahaan harus menyesuaikan diri terhadap perkembangan tersebut guna mempertahankan usaha yang dijalankannya. Terlebih lagi, dengan memasuki era Masyarakat Ekonomi ASEAN (MEA) perusahaan tentu akan menghadapi tantangan yang semakin ketat. Perusahaan perlu mengelola usahanya sedemikian rupa agar mencapai keunggulan kompetitif dibandingkan dengan para pesaingnya. Pada dasarnya tujuan didirikannya perusahaan adalah untuk mendapatkan keuntungan. Selanjutnya, perusahaan harus dapat dikelola dengan baik dengan tujuan untuk memaksimalkan nilai perusahaan. Nilai perusahaan yang tinggi akan berdampak pada kemakmuran para pemegang saham. Oleh karena itu, pengelolaan perusahaan perlu mendapat perhatian lebih agar tercapainya nilai perusahaan yang maksimal. Pengelolaan perusahaan dapat berasal dari berbagai aspek, misalnya berkaitan dengan modal yang tidak lepas dari keputusan pendanaan.

Dalam kegiatan pendanaan, ada dua sumber modal, yaitu internal financing dan external financing. Internal financing, dimana perusahaan mendapatkan dana melalui laba ditahan, sementara external financing diambil dari debt dan atau equity (Brigham dan Houston, 2006). Salah satu sumber modal perusahaan berasal dari external financing, biasanya berasal dari pinjaman dari luar perusahaan atau disebut dengan hutang. Hutang perusahaan seringkali dibandingkan dengan ekuitas yang dikenal dengan Debt to Equity Ratio (DER) yaitu rasio untuk mengetahui struktur modal perusahaan (Linda, et al. 2017). Struktur modal yang optimal dapat diartikan sebagai struktur modal yang dapat meminimalkan biaya penggunaan modal keseluruhan dan modal biaya rata-rata, sehingga dapat memaksimalkan nilai perusahaan (Linda, et al. 2017).

Penelitian yang dilakukan oleh Soleman (2008) mengenai tingkat hutang pada perusahaan publik yang terdaftar di BEI selama satu dekade, pada tahun 1993-2003 menunjukkan bahwa komposisi struktur modal masih lebih banyak didominasi oleh hutang dengan tingkat leverage di atas 60\%. Artinya, perusahaan publik di Indonesia masih bergantung pada hutang sebagai sumber pendanaan perusahaan mereka. Penentuan struktur modal tentu perlu diamati secara cermat karena akan berpengaruh terhadap nilai perusahaan. Penentuan struktur modal yang tidak optimal akan menimbulkan biaya tetap yang tinggi sehingga dapat berpengaruh buruk bagi perusahaan.

Rasio DER yang semakin tinggi menunjukkan semakin tinggi pula risiko perusahaan karena pendanaan perusahaan dari hutang semakin tinggi yang mengakibatkan laba operasi yang diperoleh perusahaan turun akibat membayar beban bunga tetap. Selain itu, menyebabkan semakin banyak aliran kas yang digunakan untuk membayar angsuran pinjaman. Ada beberapa teori yang berkaitan dengan rasio DER, salah satunya adalah Pecking Order Theory yang menyatakan bahwa urutan penggunaan dana perusahaan, jika menggunakan dana dari pihak luar perusahaan maka manajer akan lebih dahulu menggunakan hutang.

Manajer lebih menyukai penggunaan hutang untuk pendanaan dari pihak luar perusahaan dari pada penerbitan saham baru, dengan pertimbangan biaya emisi hutang jangka panjang yang lebih murah daripada penerbitan saham (Weston dan Copeland, 1997).

Keputusan pendanaan atau penentuan struktur modal tentu dipengaruhi berbagi faktor. Faktor pertama adalah profitabilitas. Menurut Marfuah dan Nurlaela (2017) profitabilitas yang tinggi maka struktur modalnya juga akan tinggi. Hal ini dikarenakan profitabilitas menunjukkan kemampuan perusahaan memperoleh laba. Dengan laba yang diperoleh semakin tinggi, maka memungkinkan untuk penawaran hutang yang semakin tinggi, dikarenakan tingkat kepercayaan kreditur terhadap perusahaan semakin besar. Selain itu, terdapat ukuran perusahaan yang mempengaruhi besarnya struktur modal perusahaan. Ukuran perusahaan yang semakin besar, artinya semakin besar pula pendanaan yang dibutuhkan untuk menjalankan usaha dari perusahaan tersebut, sehingga semakin besar pula kemungkinan peningkatan pinjaman sebagai sumber pendanaannya. Sheikh dan Qureshi (2017) juga menyatakan ada hubungan positif antara ukuran perusahaan dengan struktur modal.

Struktur modal juga dapat dipengaruhi oleh invesment opportunity set. Linda, et al. (2017) 
menjelaskan bahwa invesment opportunity set berkaitan dengan tersedianya aset riil, dan memiliki peluang dan kesempatan untuk investasi di masa depan, sehingga terjadi kombinasi diantara kedua hal tersebut. Kondisi ini menghasilkan set kesempatan investasi.

Kepemilikan manajerial adalah faktor lain yang memperngaruhi struktur modal perusahaan. Semakin besar kepemilikan manajerial maka penggunaan hutang akan semakin menurun (Jensen dan Meckling, 1976). Selain itu, kebijakan dividen juga mempengaruhi struktur modal dimana dengan adanya kebijakan dividen yang tinggi mengakibatkan laba ditahan sebagai sumber pendanaan menurun sehingga dapat memicu kenaikan penggunaan hutang. Suryani dan Khafid (2015) menyatakan kebijakan dividen berpengaruh positif terhadap struktur modal.

Penelitian yang berkaitan dengan faktor-faktor apa saja yang memengaruhi struktur modal atau keputusan pendanaan perusahaan telah dilakukan sebelumnya oleh berbagai peneliti. Namun, masih banyak hasil penelitian yang belum konklusi dikarenakan perbedaan waktu, tempat, populasi, jumlah sampel penelitian, dan lain-lain. Penelitian Marfuah dan Nurlaela (2017) menunjukkan bahwa secara parsial ukuran perusahaan dan profitabilitas berpengaruh signifikan terhadap struktur modal. Berbanding terbalik dengan penelitian yang dilakukan oleh Tangiduk, et al. (2017) yang meneliti tema serupa menunjukkan bahwa ukuran perusahaan tidak berpengaruh dan tidak signifkan terhadap struktur modal. Begitu pula dengan profitabilitas yang tidak berpengaruh dan tidak signifikan terhadap struktur modal.

Penelitian Ramli dan Papilaya (2015) menemukan bahwa invesment opportunity set berpengaruh positif terhadap struktur modal, berbanding terbalik dengan penelitian dari Fitriyah dan Hidayat (2011) yang menyatakan bahwa IOS berpengaruh negatif terhadap DER. Menurut Wimelda dan Marlinah (2013) kepemilikan manajerial berpengaruh negatif terhadap struktur modal, sedangkan Mardiyati, dkk (2018) menyatakan tidak ada pengaruh kepemilikan manajerial terhadap kebijakan hutang. Sheisarvian, dkk (2015) menyatakan kebijakan dividen berpengaruh negatif terhadap struktur modal, sedangkan Suryani dan Khafid (2015) berpendapat ada hubungan positif antara kebijakan dividen dengan struktur modal.

Hasil yang berbeda pada pengujian tentang pengaruh struktur modal terhadap nilai perusahaan juga ditemukan. Penelitian Manoppo dan Arie (2016) menunjukkan bahwa struktur modal berpengaruh positif signifikan terhadap nilai perusahaan. Pengaruh tersebut diperkuat dengan penelitian dari Hasania, dkk (2016) yang menyatakan hal serupa. Berbanding terbalik dengan penelitian yang dilakukan oleh Manihuruk, et al. (2016) yang menyatakan bahwa struktur modal tidak berpengaruh signifikan terhadap nilai perusahaan.

Adanya research gap pada literatur terdahulu menjadi dasar dalam penelitian ini untuk mengkaji lebih lanjut mengenai struktur modal. Belum ada penelitian yang menguji pengaruh efek anteseden struktur modal secara komprehensif dalam kaitannya dengan nilai perusahaan. Penelitian ini menguji efek anteseden struktur modal terhadap nilai perusahaan. Pengujian efek anteseden struktur modal dilakukan dengan menggunakan metoda factor analysis, sehingga diperoleh suatu faktor yang komposisinya merupakan keterwakilan (representative) pengukuran efek anteseden atas variabel struktur modal dalam keterkaitannya dengan nilai perusahaan.

\section{B. LANDASAN TEORI DAN PENGEMBANGAN HIPOTESIS}

\section{Modigliani and Miller (MM) Theory}

Teori Modigliani and Miller merupakan teori yang pertama kali dikemukakan oleh Modigliani dan Miller (1958). Teori ini lebih dikenal dengan teori MM. Teori MM menyatakan bahwa nilai perusahaan dan weighted average cost of capital (WACC) tidak dipengaruhi oleh struktur modal perusahaan. Namun, asumsi pasar sempurna dari MM seperti tidak ada biaya transaksi, tidak ada pajak, informasi simetris, tingkat bunga meminjam sama dengan tingkat bunga meminjamkan sebesar tingkat bunga bebas risiko adalah bertentangan dengan keadaan dalam dunia nyata (Rustam, 2015). Menurut Brigham dan Houston (2006) teori Modigliani dan Miller terbagi menjadi 2 kondisi, yaitu (1) tanpa pajak, diasumsikan bahwa jika tidak ada pajak perusahaan maka tidak terdapat pengaruh financial leverage terhadap nilai perusahaan. 
(2) dengan pajak perusahaan, dinyatakan bahwa nilai perusahaan yang memiliki hutang akan lebih besar daripada nilai perusahaan yang tidak memiliki hutang.

\section{Agency Theory}

Agency theory atau teori keagenan berkaitan dengan hubungan antara principal dan agent yang didalamnya terdapat kontrak kerjasama yang mengikat. Menurut Jensen dan Meckling (1976) menjelaskan teori keagenan sebagai hubungan antara agent (manajemen suatu usaha) dan principal (pemilik usaha). Di dalam hubungan tersebut terdapat perbedaan kepentingan keduanya sehingga memicu munculnya konflik (masalah keagenan). Jensen dan Meckling (1976) mengemukakan bahwa pemisahan atau perbedaan pengawasan dan struktur kepemilikan dapat meningkatkan biaya keagenan (agency cost). Terdapat beberapa cara yang dapat dilakukan untuk dapat mengurangi biaya keagenan seperti meningkatkan kepemilikan dari dalam (insider ownership) atau kepemilikan manajerial, dan meningkatkan dividen payout ratio.

\section{Pecking Order Theory}

Pecking order theory dikemukakan oleh Myers dan Majluf pada tahun 1984 yang berkaitan dengan urutan keputusan pendanaan. Manajer akan lebih dahulu memilih menggunakan dana laba ditahan, lalu menggunakan hutang, dan menerbitkan saham sebagai pilihan terakhir. Menurut Weston dan Copeland (1997) Manajer lebih menyukai penggunaan hutang untuk pendanaan dari pihak luar perusahaan dari pada penerbitan saham baru, karena pertimbangan biaya emisi hutang jangka panjang yang lebih murah daripada penerbitan saham.

\section{Kerangka Pemikiran}

Penelitian ini didasarkan pada kerangka pemikiran berikut:

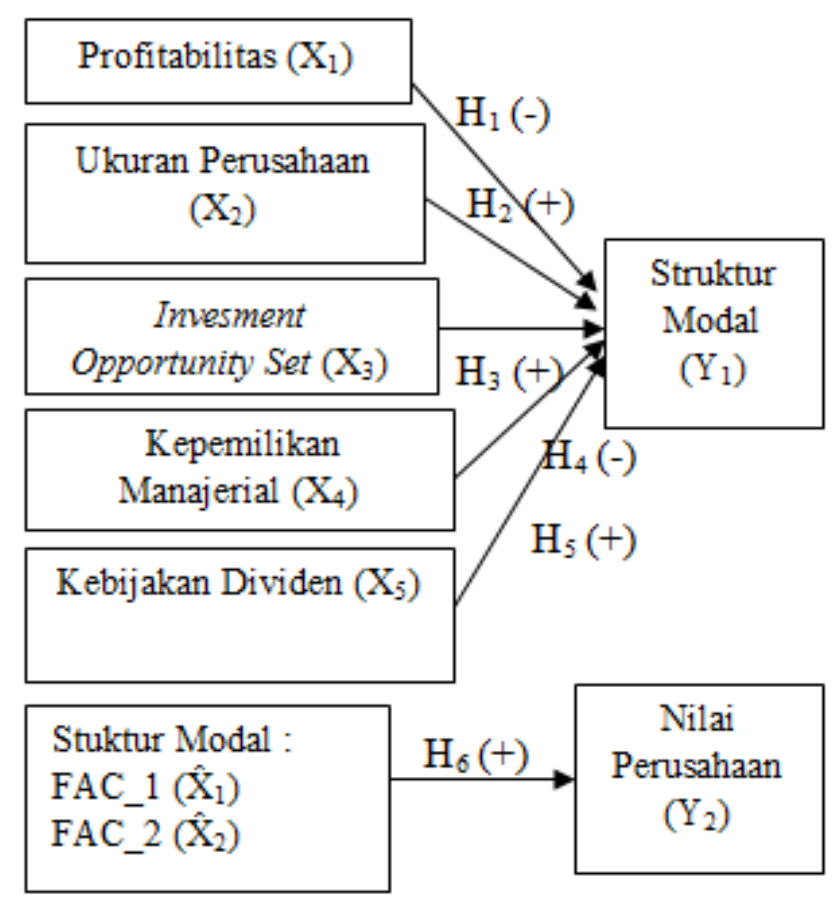

Menurut Hastalona (2013) mendefinisikan profitabilitas adalah tingkat keuntungan bersih yang berhasil diperoleh perusahaan dalam menjalankan operasionalnya dalam suatu periode. Apabila profitabilitas atau laba perusahaan besar maka kemungkinan besar perusahaan akan dipandang oleh para investor atau kreditur memiliki prospek masa depan yang lebih bagus. Perusahaan yang memiliki profitabilitas yang tinggi cenderung akan mengurangi penggunaan hutang sebagai sumber pendanaannya.

Hal ini sesuai dengan Pecking Order Theory yang mengemukakan bahwa perusahaan cenderung menggunakan sumber pendanaan internal sebanyak mungkin sebelum memutuskan untuk berhutang (Angelya dan Arilyn, 2017). Hasil penelitian dari Masnoon dan Saeed (2014) dan Atiqoh (2016) variabel 
ini berpengaruh negatif terhadap struktur modal. Artinya, semakin tinggi profitabilitas maka semakin kecil proporsi penggunaan hutang sebagai pendanaan atau struktur modal perusahaan. Berdasarkan uraian tersebut, maka hipotesis pertama yang diajukan adalah:

\section{H1: Profitabilitas berpengaruh negatif terhadap struktur modal.}

Ukuran perusahaan merupakan salah satu faktor yang dipertimbangkan perusahaan dalam menentukan seberapa besar kebijakan keputusan pendanaan (struktur modal). Ukuran perusahaan menurut Riyanto (2010) menggambarkan besar kecilnya suatu perusahaan yang ditunjukkan dari total aktiva, jumlah penjualan, rata-rata penjualan dan rata-rata total aktiva. Ukuran besar kecilnya perusahaan ini diukur melalui logaritma natural dari total aset (Ln total aset). Total aset dijadikan sebagai indikator ukuran perusahaan karena sifatnya jangka panjang dibandingkan dengan penjualan (Titman dan Wessels, 1988). Apabila perusahaan semakin besar maka semakin besar pula dana yang akan dikeluarkan, baik itu dari kebijakan hutang atau modal sendiri (equity) dalam mempertahankan atau mengembangkan perusahaan.

Ukuran perusahaan sering dijadikan indikator bagi kemungkinan terjadinya kebangkrutan bagi suatu perusahaan, dimana perusahaan dengan ukuran lebih besar dipandang lebih mampu mengahadapi krisis dalam menjalankan usahanya. Hal ini akan mempermudah perusahaan dengan ukuran besar untuk memperoleh pinjaman dari kreditur. Dapat disimpulkan bahwa perusahaan yang lebih besar akan lebih mudah mendapat pendanaan dari hutang karena memiliki nilai aset yang dijadikan jaminan lebih tinggi sehingga para pemberi pinjaman akan merasa lebih aman. Hal ini selaras dengan penelitian yang dilakukan Sheikh dan Qureshi (2017) dan Marfuah dan Nurlaela (2017) yang menyatakan bahwa semakin besar nilai ukuran perusahaan maka semakin besar juga struktur modal pada perusahaan. Oleh karena itu, hipotesis kedua yang diajukan adalah:

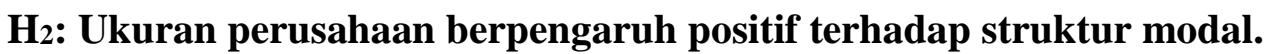

Perusahaan yang memiliki kesempatan investasi atau pertumbuhan yang tinggi akan cenderung menggunakan hutang yang lebih besar. Kebutuhan dana pada perusahaan akan semakin besar seiring dengan semakin tingginya pertumbuhan perusahaan. Oleh karena itu, mendorong perusahaan untuk menggunakan lebih banyak hutang. Hal itu diperkuat oleh penelitian Ramli dan Papilaya (2015) serta Linda, et al. (2017) yang menyatakan bahwa semakin besar IOS atau kesempatan investasi perusahaan, maka perusahaan cenderung menggunakan hutang lebih banyak dalam struktur modalnya. Berdasarkan uraian tersebut, maka hipotesis ketiga yang dapat diajukan adalah:

\section{H3: Invesment opportunity set berpengaruh positif terhadap struktur modal.}

Kepemilikan manajerial merupakan salah satu faktor yang dapat mempengaruhi struktur modal. Jensen dan Meckling (1976) menyatakan bahwa salah satu cara untuk memperkecil kemungkinan adanya konflik dalam perusahaan akibat agent dan principal adalah dengan cara memperbesar kepemilikan manajerial. Semakin besar kepemilikan manajerial maka akan semakin kecil penggunaan hutang perusahaan. Pengaruh negatif tersebut diperkuat oleh penelitian dari Wimelda dan Marlinah (2013) serta Sheisarvian, dkk (2015). Berdasarkan uraian tersebut, maka hipotesis keempat yang dapat diajukan adalah:

\section{H4: Kepemilikan manajerial berpengaruh negatif terhadap struktur modal.}

Struktur modal dapat dipengaruhi oleh kebijakan dividen yang berkaitan dengan tinggi rendahnya laba ditahan suatu perusahaan. Pecking order theory menjelaskan bahwa urutan pertama pendanaan perusahaan berasal dari internal financing yaitu laba ditahan, kemudian disusul dengan external financing berupa hutang. Apabila laba ditahan dirasa cukup sebagai sumber pendanaan maka tidak diperlukan lagi external financing. Oleh karena itu, apabila kebijakan dividen menetapkan dividen yang dibagikan lebih besar maka laba ditahan perusahaan akan semakin kecil sehingga diperlukan lebih banyak external financing berupa hutang. Pengaruh positif antara kebijakan dividen dengan struktur modal diperkuat oleh penelitian dari Suryani dan Khafid (2015). Berdasarkan uraian tersebut, maka hipotesis kelima yang dapat diajukan adalah: 


\section{H5: Kebijakan dividen berpengaruh positif terhadap struktur modal}

Struktur modal merupakan perbandingan antara modal dari luar perusahaan yang biasanya berupa hutang jangka panjang dengan modal sendiri (shareholder's equity) sebagai sumber pembiayaan perusahaan. Perusahaan dengan prospek masa depan yang baik memerlukan pendanaan yang besar untuk membiayai operasional usahanya yang berkiatan dengan keinginan para pemgang saham untuk memaksimalkan nilai perusahaan demi terwujudnya kemakmuran para pemegang saham. Oleh karena itu, struktur modal akan berpengaruh terhadap nilai perusahaan. Sesuai dengan teori MM yang menyatakan bahwa nilai perusahaan akan meningkat seiring dengan penggunaan hutang dengan asumsi adanya pajak karena biaya bunga hutang dapat dijadikan pengurang dalam pembayaran pajak. Linda, et al (2017) juga menyatakan bahwa dengan penggunaan struktur modal yang optimal akan meningkatkan nilai perusahaan. Penelitian dari Manoppo dan Arie (2016) dan Hasania, dkk (2016) memperkuat bahwa struktur modal berpengaruh positif signifikan terhadap nilai perusahaan. Berdasarkan uraian tersebut, maka hipotesis keenam yang dapat diajukan adalah:

\section{H6: Struktur modal berpengaruh positif terhadap nilai perusahaan.}

\section{METODE PENELITIAN}

Penelitian ini menggunakan data sekunder berupa laporan keuangan tahunan perusahaan yang bersumber dari website Bursa Efek Indonesia (www.idx.co.id). Populasi penelitian ini adalah perusahaan manufaktur yang terdaftar di Bursa Efek Indonesia periode 2012-2017. Teknik pengambilan sampel menggunakan purposive sampling sehingga diperoleh sampel sebanyak 41 perusahaan, seperti yang dijelaskan pada Tabel 1. Adapun daftar perusahaan sampel yang digunakan pada penelitian ini seperti pada Lampiran 1

Tabel 1 Hasil Purposive Sampling

\begin{tabular}{clc}
\hline No & \multicolumn{1}{c}{ Keterangan } & Jumlah \\
\hline \hline 1 & Perusahaan manufaktur yang terdaftar di BEI tahun 2012-2017 & 157 \\
2 & $\begin{array}{l}\text { Perusahaan yang tidak menerbitkan laporan keuangan berturut-turut } \\
\text { selama tahun 2012-2017 }\end{array}$ & $(31)$ \\
3 & $\begin{array}{l}\text { Perusahaan yang mengalami kerugian selama periode penelitian yaitu } \\
\text { tahun 2012-2017 }\end{array}$ & $(61)$ \\
4 & $\begin{array}{l}\text { Perusahaan yang tidak memiliki data yang lengkap terkait variabel } \\
\text { penelitian selama periode penelitian yaitu tahun 2012-2017 }\end{array}$ & $(24)$ \\
\hline Total sampel perusahaan per tahun & $\mathbf{4 1}$ \\
Total sampel perusahaan tahun 2012-2017 & $\mathbf{2 4 6}$ \\
\hline \hline
\end{tabular}

\section{Definisi dan Operasionalisasi Variabel}

\section{Profitabilitas}

Profitabilitas adalah kemampuan perusahaan memperoleh laba dalam hubungannya dengan penjualan, total aktiva, maupun modal sendiri (Sartono, 2010). Menurut Kasmir (2016) rasio profitabilitas merupakan rasio yang menilai kemampuan perusahaan dalam mencari keuntungan. Dalam hal ini rasio profitabilitas diukur menggunakan rasio Return on Assets (ROA). ROA digunakan untuk menunjukkan kemampuan perusahaan menghasilkan laba dengan menggunakan total aset yang dimiliki (Kasmir, 2016). Semakin tinggi ROA menunjukkan semakin tinggi pula laba yang diperoleh dan menunjukkan semakin baik posisi perusahaan dari segi penggunaan asetnya. Return on Assets dapat diformulasikan sebagai berikut: 


$$
R O A=\frac{\text { Laba bersih sesudah pajak }}{\text { Total aset }}
$$

\section{Ukuran Perusahaan}

Ukuran perusahaan (firm size) merupakan besarnya aktiva yang dimiliki oleh perusahaan, sehingga perusahaan mempunyai kekuatan lebih dalam memperoleh pendanaan eksternal dalam kemudahan masuk ke pasar modal, dikarenakan perusahaan besar memiliki nilai jaminan yang besar (Himawan dan wibowo, 2016). Ukuran perusahaan diproksikan dengan nilai logaritma natural dari total aktiva. (Hartono, 2015). Merujuk pada penelitian Marfuah dan Nurlaela (2017) secara sistematis ukuran perusahaan dapat diformulasikan sebagai berikut:

$$
\text { Ukuran perusahaan }=\mathrm{Ln} \text { (total aset) }
$$

\section{Invesment Opportunity Set}

Invesment opportunity set (IOS) menurut Gaver dan Gaver (1993) yang dikutip oleh Hidayah (2015) bersifat tidak dapat diobservasi karena merupakan variabel tersembunyi (laten) sehingga untuk dapat mengetahui ukuran suatu IOS maka diperlukan proksi IOS. Secara umum proksi IOS diklasifikasikan menjadi tiga jenis utama, yaitu berdasarkan harga (price-based proxies), berdasarkan investasi (investmentbased proxies), dan berdasarkan varian (variance measures). Hasil penelitian Adam dan Goyal (2008) menunjukkan bahwa rasio book-to-market of assets dan equity adalah salah satu proksi potensi pertumbuhan yang valid, selain itu mempunyai korelasi paling tinggi dengan pertumbuhan perusahaan pada masa yang akan datang. Oleh karena itu, penulis memilih menggunakan proksi MVE/BVE (market to book value of equity) yang termasuk dalam kategori proksi berdasarkan harga. Merujuk pada penelitian Linda, et al. (2017) MVE/BVE diformulasikan sebagai berikut.

$$
\text { MVE/BVE }=\frac{\text { Lembar saham yang beredar } \mathrm{x} \text { harga penutupan }}{\text { Total ekuitas }}
$$

\section{Kepemilikan Manajerial}

Kepemilikan manajerial merupakan suatu keadaan dimana manajer memiliki saham dalam perusahaan atau dengan kata lain bertindak sebagai pemegang saham juga. Merujuk pada penelitian Sheisarvian, dkk (2015) kepemilikan saham dapat dirumuskan sebagai berikut.

$$
\text { Kepemilikan manajerial }=\frac{\text { Jumlah saham manajerial }}{\text { Jumlah saham yang beredar }} \times 100 \%
$$

\section{Kebijakan Dividen}

Kebijakan dividen merupakan kebijakan yang berkaitan dengan keputusan seberapa besar proporsi laba yang akan dibagikan kepada pemegang saham dalam bentuk dividen atau tidak membagikannya dalam bentuk laba ditahan yang dapat digunakan sebagai pendanaan perusahaan. Menurut Sartono (2010) besar kecilnya dividen sangat tergantung besar kecilnya laba yang diperoleh dan proporsi laba yang dibagikan dalam bentuk dividen atau dividend payout ratio. Oleh karena itu, penelitian ini menggunakan dividend payout ratio (DPR) untuk melihat kebijakan dividen. Dividend payout ratio dapat dirumuskan sebagai berikut.

$$
D P R=\frac{\text { Dividen per saham }}{\text { Laba bersih per saham }}
$$

Adapun laba bersih per saham (EPS) dapat dihitung dengan rumus sebagai berikut.

$$
E P S=\frac{\text { Pendapatan setelah pajak }}{\text { Jumlah saham yang beredar }}
$$




\section{Struktur Modal}

Struktur modal merupakan perimbangan jumlah hutang jangka pendek yang bersifat permanen, hutang jangka panjang, saham preferen dan saham biasa. Dalam hal ini struktur modal diproksikan dengan Debt to Equity Ratio (DER). Menurut Kasmir (2016) DER merupakan rasio yang digunakan untuk menilai utang dengan ekuitas. Nilai DER yang semakin kecil menandakan bahwa perusahaan memiliki jaminan terhadap penggunaan hutang yang lebih besar dan sebaliknya. Merujuk pada Brigham dan Houston (2006) DER dapat diformulasikan sebagai berikut:

$$
D E R=\frac{\text { Total liabilitas }}{\text { Total ekuitas }}
$$

\section{Nilai Perusahaan}

Nilai perusahaan adalah harga yang bersedia dibayar oleh calon pembeli apabila perusahaan tersebut dijual (Husnan, 2013). Nilai perusahaan dapat dianalisis melalui beberapa rasio seperti Price Earning Ratio (PER), Price Book Value Ratio (PBV), Market Book Ratio (MBR), Dividen Yield Ratio, serta Tobin's Q. Penelitian ini menggunakan Tobin's Q dalam mengukur nilai perusahaaan. Tobin's Q adalah indikator untuk mengukur kinerja perusahaan, khususnya tentang nilai perusahaan, yang menunjukkan suatu proforma manajemen dalam mengelola aktiva perusahaan (Sudiyatno dan Puspitasari, 2010). Alasan penulis menggunakan Tobin's Q karena adanya beberapa keunggulan dari pengukuran ini, seperti mencerminkan modal intelektual perusahaan, mencerminkan sentimen pasar dan lainnya (Smithers dan Wright, 2008). Rumus Tobin's Q menurut Smithers dan Wright (2008) yaitu:

$$
T Q=\frac{\mathrm{EMV}+\mathrm{D}}{\mathrm{EBV}+\mathrm{D}}
$$

Keterangan:

$\begin{array}{ll}\text { TQ } & : \text { Nilai perusahaan } \\ \text { EMV } & : \text { Nilai pasar ekuitas }(\text { EMV }=\text { Closing price } \times \text { Jumlah saham }) \\ \text { D } & : \text { Nilai buku dari total hutang } \\ \text { EBV } & : \text { Nilai buku dari total ekuitas }\end{array}$

Penelitian ini menguji variabel-variabel independen yang lebih dari satu terhadap variavel dependennya sehingga menggunakan model regresi linier berganda. Model regresi linier berganda tersebut sebagai berikut:

$$
\begin{aligned}
& \text { Model } 1 \text { DER }=\alpha_{0}+\beta_{1} X_{1}+\beta_{2} X_{2}+\beta_{3} X_{3}+\beta_{4} X_{4}+\beta_{5} X_{5}+\varepsilon \\
& \text { Model } 2 \text { TQ }=\alpha_{0}+\beta_{1} \hat{X}_{1}+\beta_{2} \hat{X}_{2}+\varepsilon
\end{aligned}
$$

Keterangan:

$\begin{array}{ll}\text { DER } & : \text { Debt to Equity Ratio } \\ \text { TQ } & : \text { Tobin's Q } \\ \alpha 0 & : \text { Konstanta } \\ \beta 1, \beta 2, \beta 3, \beta 4 & : \text { Koefisien regresi } \\ \mathrm{X} 1 & : \text { Profitabilitas } \\ \mathrm{X} 2: & \text { Ukuran perusahaan } \\ \mathrm{X} 3 & : \text { Invesment opportunity set } \\ \mathrm{X} 4 & : \text { Kepemilikan manajerial } \\ \mathrm{X} 5 & : \text { Kebijakan dividen } \\ \hat{\mathrm{X}}_{1} & : \text { FAC_1 } \\ \hat{\mathrm{X}}_{2} & : \text { FAC_2 } \\ \varepsilon & : \text { Variabel pengganggu }\end{array}$


D. ANALISIS DAN PEMBAHASAN

Tabel 2 Hasil Uji Statistik Deskriptif

\begin{tabular}{cccrlc}
\hline Keterangan & N & Minimum & Maksimum & Rata-rata & Standar Deviasi \\
\hline \hline ROA & 246 & 0,00084 & 0,40377 & 0,0965802 & 0,08694593 \\
SIZE & 246 & 25,57957 & 33,32035 & 28,4033562 & 1,62335867 \\
IOS & 246 & 0,00193 & 82,44443 & 4,0037017 & 9,39654131 \\
KM & 246 & 0,00000 & 0,38027 & 0,0385705 & 0,07737219 \\
DPR & 246 & 0,00000 & 4,59277 & 0,3259337 & 0,46900009 \\
DER & 246 & 0,00057 & 5,15242 & 0,9001750 & 0,78529627 \\
TQ & 246 & 0,17797 & 23,28575 & 2,3844011 & 3,18685645 \\
\hline \hline
\end{tabular}

\section{Pengujian Hipotesis}

1) Uji Koefisien Determinasi (Uji $\left.\mathbf{R}^{2}\right)$

Tabel 3 Hasil Uji Koefisien Determinasi (Uji $\mathbf{R}^{2}$ )

\begin{tabular}{ccc}
\hline \multicolumn{3}{c}{ Model Summary $^{\mathbf{b}}$} \\
\hline Model Regresi & R Square & Adjusted R Square \\
\hline \hline M1 & 0,260 & 0,245 \\
M2 & 0,838 & 0,837 \\
\hline \hline
\end{tabular}

Pengujian hipotesis ini telah lolos uji asumsi klasik. Pada Tabel 3 untuk model regresi 1 dapat diketahui bahwa koefisien determinasi yaitu Adjusted $R$ Square (Adj R ${ }^{2}$ ) memiliki nilai 0,245 atau 24,5\%. Hasil ini menunjukkan bahwa kemampuan variabel independen dalam menjelaskan variabel dependen yaitu struktur modal sebesar 24,5\%, sedangkan sisanya sebesar 75,5\% dipengaruhi oleh variabel lain. Sedangkan, untuk model regresi 2 dapat diketahui bahwa koefisien determinasi memilki nilai 0,837 atau $83,7 \%$. Nilai tersebut menunjukkan bahwa kemampuan variabel struktur modal dalam menjelaskan variabel nilai perusahaan sebesar $83,7 \%$, sedangkan sisanya sebesar $16,3 \%$ dipengaruhi oleh variabel lain yang tidak dapat dijelaskan dalam penelitian ini.

\section{2) Uji Kelayakan Model Regresi (Uji Statistik F)}

\section{Tabel 4 Hasil Uji Statistik F}

ANOVA ${ }^{\mathrm{a}}$

\begin{tabular}{ccc}
\hline Model Regresi & F & Sig. \\
\hline \hline M1 & 16,864 & $0,000^{\mathrm{b}}$ \\
M2 & 630,447 & $0,000^{\mathrm{b}}$ \\
\hline \hline
\end{tabular}

Pada Tabel 4 dapat diketahui bahwa model regresi 1 memiliki nilai $\mathrm{F}$ sebesar 16,864 dengan signifikansi 0,000, serta model regresi 2 memiliki nilai $F$ sebesar 630,447 dengan signifikansi 0,001 (signifikansi $<0,05$ ). Nilai tersebut menunjukkan nilai signifikansi $\mathrm{F}<0,05$, artinya baik model regresi 1 maupun model regresi 2 bersifat fit dan layak untuk dilakukan penelitian selanjutnya. 
Tabel 5 Hasil Uji Statistik t

Coefficients $^{\mathbf{a}}$

\begin{tabular}{llrrrc}
\hline $\begin{array}{c}\text { Model } \\
\text { Regresi }\end{array}$ & \multicolumn{2}{c}{$\begin{array}{c}\text { Unstandardized } \\
\text { Coefficients } \\
\text { B }\end{array}$} & t & Sig. & $\begin{array}{c}\text { Kesimpulan } \\
\text { Hipotesis }\end{array}$ \\
\hline M1 & (Constant) & 2,291 & 2,648 & 0,009 & \\
& ROA & $-5,027$ & $-7,050$ & 0,000 & Terdukung \\
& SIZE & $-0,036$ & $-1,163$ & 0,246 & Tidak terdukung \\
& IOS & 0,049 & 7,738 & 0,000 & Terdukung \\
& KM & $-2,056$ & $-3,411$ & 0,001 & Terdukung \\
& DPR & $-0,032$ & $-0,311$ & 0,756 & Tidak terdukung \\
\hline M2 & (Constant) & 2,384 & 29,074 & 0,000 & \\
& FAC_1 & 2,879 & 35,031 & 0,000 & Terdukung \\
& FAC_2 & 0,477 & 5,805 & 0,000 & Terdukung \\
\hline \hline
\end{tabular}

Sumber: Pengolahan Data dengan SPSS 24

\section{Pembahasan}

\section{Pengaruh Profitabilitas terhadap Struktur Modal}

Pada hasil penelitian ini diketahui adanya pengaruh negatif dan signifikan profitabilitas terhadap struktur modal, sehingga hipotesis pertama yaitu profitabilitas berpengaruh negatif terhadap struktur modal, terdukung.

Profitabilitas dalam penelitian ini diukur menggunakan Return On Asset (ROA) yang menunjukkan kemampuan perusahaan dalam menghasilkan laba dengan menggunakan total aset yang dimiliki. Semakin tinggi nilai ROA artinya semakin baik posisi perusahaan dalam penggunaan asetnya. Berdasarkan hasil penelitian ini adanya pengaruh yang signifikan yang berarti profitabilitas merupakan salah satu elemen penting dalam pengambilan keputusan struktur modal. Perusahaan yang memiliki laba yang lebih besar akan memilih untuk menggunakan laba tersebut sebagai sumber pendanaan dan mengurangi sumber pendanaan dari external financing, seperti penggunaan hutang.

Hasil penelitian ini mendukung Pecking Oreder Theory yang menyatakan bahwa perusahaan cenderung menggunakan sumber pendanaan internal sebanyak mungkin sebelum memutuskan untuk berhutang. Selain itu, hasil penelitian ini konsisten dengan penelitian Masnoon dan Saeed (2014) dan Atiqoh (2016) yang menyatakan bahwa profitabilitas memiliki pengaruh negatif dan signifikan terhadap struktur modal. Namun, tidak konsisten dengan hasil penelitian dari Tangiduk, et al. (2017) dan Maryanti (2016) yang menyatakan bahwa profitabilitas tidak berpengaruh terhadap struktur modal.

\section{Pengaruh Ukuran Perusahaan terhadap Struktur Modal}

Ukuran perusahaan dalam penelitian ini diketahui tidak berpengaruh terhadap struktur modal, sehingga hipotesis kedua yang menyatakan bahwa ukuran perusahaan berpengaruh positif terhadap struktur modal tidak terdukung.

Ukuran perusahaan menggambarkan besar kecilnya suatu perusahaan yang ditunjukkan dari total aset, jumlah penjualan, rata-rata penjualan dan rata-rata total aset, dimana ukuran perusahaan dapat diukur menggunakan logaritma natural dari total aset (Ln total aset). Semakin besar ukuran perusahaan menunjukkan semakin besar pula kebutuhan pendanaan untuk mempertahankan atau mengembangkan perusahaannya. 
Ukuran perusahaan sering dijadikan indikator bagi kemungkinan terjadinya kebangkrutan bagi suatu perusahaan, dimana perusahaan dengan ukuran lebih besar dipandang lebih mampu mengahadapi krisis dalam menjalankan usahanya. Hal ini akan mempermudah perusahaan dengan ukuran besar untuk memperoleh pinjaman dari kreditur. Namun berdasarkan hasil penelitian ini, ukuran perusahaan tidak berpengaruh terhadap struktur modal, artinya ukuran perusahaan bukan merupakan faktor penentu struktur modal. Ukuran perusahaan yang besar tidak menjamin perusahaan untuk memilih menggunakan hutang yang lebih besar, karena dengan ukuran perusahaan yang lebih besar dapat memungkinkan untuk mendapatkan dana dari luar berupa transaksi saham dalam pasar modal atau lebih memilih menggunakan profit perusahaan semaksimal mungkin yang tidak memiliki risiko seperti penggunaan hutang. Hasil penelitian ini konsisten dengan penelitian Tangiduk, et al. (2017) yang menyatakan bahwa ukuran perusahaan tidak berpengaruh dan tidak signifikan terhadap struktur modal. Namun, tidak konsisten dengan penelitian Tamam dan Wibowo (2017) serta Darajati dan Hartomo (2015) yang menyatakan adanya pengaruh positif dan signifikan ukuran perusahaan terhadap struktur modal.

\section{Pengaruh Invesment Opportunity Set terhadap Struktur Modal}

Pada penelitian ini menunjukkan adanya pengaruh positif dan signifikan investment opportunity set terhadap struktur modal, sehingga hipotesis ketiga yaitu investment opportunity set berpengaruh positif terhadap struktur modal, terdukung.

Investment opportunity set (IOS) merupakan suatu kombinasi antara aktiva riil dengan kesempatan di masa depan yang dapat menghasilkan nilai perusahaan. Perusahaan yang memiliki kesempatan di masa depan yang baik akan memanfaatkannya untuk mengembangkan usahanya yang dapat meningkatkan nilai perusahaan. Terdapat beberapa pengukuran IOS yang dapat digunakan salah satunya adalah berdasarkan harga yaitu menggunakan market to book value of equity.

Berdasarkan hasil penelitian ini menunjukkan adanya pengaruh yang signifikan variabel investment opportunity set terhadap struktur modal, artinya variabel ini memiliki peran yang cukup penting dalam keputusan pendanaan atau struktur modal. Jika investment opportunity set mengalami peningkatan, maka perusahaan akan cenderung meningkatkan pula struktur modalnya berupa penggunaan hutang (external financing) untuk mencukupi kebutuhan peningkatan investasi tersebut. Hal ini sejalan dengan penelitian dari Ramli dan Papilaya (2015) dan Linda, et al. (2017) yang menyatakan semakin tinggi IOS maka perusahaan akan menggunakan hutang lebih banyak dalam struktur modalnya. Namun, tidak konsisten dengan hasil penelitian dari Fitriyah dan Hidayat (2011) yang menyatakan bahwa investment opportunity set berpengaruh negatif signifikan terhadap struktur modal.

\section{Pengaruh Kepemilikan Manajerial terhadap Struktur Modal}

Kepemilikan manajerial jika dilihat dari hasil penelitian ini memiliki pengaruh negatif dan signifikan terhadap struktur modal, sehingga hipotesis keempat yang menyatakan bahwa kepemilikan manajerial berpengaruh negatif terhadap struktur modal, terdukung.

Kepemilikan manajerial menunjukkan adanya persentase kepemilikan saham perusahaan yang dimiliki oleh pihak manajerial perusahaan tersebut. Hal ini mengindikasikan bahwa kepemilikan manajerial menjadi salah satu faktor dalam penentuan struktur modal perusahaan manufaktur di Indonesia.

Konflik kepentingan antara agen dengan principal atau biasa disebut dengan masalah agensi dapat dikurangi dengan adanya kepemilikan manajerial didalamnya, karena dalam pengelolaan perusahaan, manajemen memiliki peran yang sangat penting, di mana manajemen lebih paham berkaitan informasi pengelolaan perusahaan dan prospek perusahaan di masa depan. Oleh karena itu, dengan adanya kepemilikan manajerial dapat berpengaruh terhadap keputusan penggunaan hutang yang dilakukan perusahaan. Semakin tinggi kepemilikan manajerial, maka semakin rendah struktur modal atau penggunaan hutang perusahaan. Hal itu menunjukkan tingginya intervensi pemilik saham yang sekaligus sebagai pihak manajemen dalam penentuan keputusan penggunaan hutang tersebut. 
Pengaruh negatif yang ditunjukkan dari hasil uji t menunjukkan bahwa semakin besar kepemilikan manajerial maka akan semakin besar pula peran manajerial untuk memperkecil penggunaan hutang dalam struktur modal perusahaan. Hal ini selasar dengan penelitian Sheisarvian, dkk (2015) dan Wimelda dan Marlinah (2013) yang menyatakan bahwa kepemilikan manajerial memiliki pengaruh negatif dan signifikan terhadap struktur modal. Namun, tidak selaras dengan penelitian Sari, dkk (2013) yang menyatakan kepemilikan manajerial tidak berpengaruh terhadap struktur modal.

\section{Pengaruh Kebijakan Dividen terhadap Struktur Modal}

Hasil uji t sebelumnya menunjukkan bahwa kebijakan dividen tidak berpengaruh terhadap struktur modal. Dengan demikian, hipotesis kelima, yaitu kebijakan dividen berpengaruh positif terhadap struktur modal, tidak terdukung.

Hasil penelitian ini menunjukkan tidak adanya pengaruh kebijakan dividen terhadap struktur modal, artinya semakin tinggi kebijakan dividen yang ditetapkan perusahaan tidak menjamin bahwa semakin rendah laba ditahan yang dimiliki perusahaan sehingga membutuhkan asupan dana dari luar, yaitu dari hutang. Namun, semakin tinggi kebijakan dividen atau semakin tingginya dividen yang dibagikan perusahaan mengindikasikan bahwa perusahaan sedang dalam kondisi yang baik dan memperoleh laba yang lebih besar (profitabilitas tinggi), sehingga dalam kondisi tersebut perusahaan memiliki kemampuan lebih untuk membiayai kebutuhan operasionalnya sendiri, tanpa berpengaruh terhadap penggunaan hutang. Selain itu, dengan adanya kebijakan dividen yang tinggi memungkinkan para investor memberikan respon positif terhadap perusahaan sehingga jika perusahaan tetap menginginkan dana dari luar maka lebih mudah mendapatkannya dari transaksi saham di pasar modal dibandingkan harus menggunakan hutang.

Hipotesis kelima yang dinyatakan tidak terdukung, di mana tidak adanya pengaruh kebijakan dividen terhadap struktur modal selaras dengan penelitian yang dilakukan oleh Wimelda dan Marlinah (2013) serta Sari, dkk (2013). Namun, tidak selaras dengan penelitian dari Larasati (2011) dan Sheisarvian, dkk (2015) yang menyatakan bahwa kebijakan dividen berpengaruh negatif signifikan terhadap struktur modal.

\section{Pengaruh Struktur Modal terhadap Nilai Perusahaan}

Hasil uji t sebelumnya menunjukkan variabel struktur modal memiliki hubungan positif dan signifikan terhadap nilai perusahaan. Oleh karena itu, hipotesis keenam yaitu struktur modal berpengaruh positif terhadap nilai perusahaan, terdukung.

Nilai perusahaan merupakan hal penting bagi para pemegang, di mana nilai perusahaan yang tinggi dapat berdampak baik bagi kemakmuran pemegang saham. Dengan demikian, pengelolan perusahaan perlu diperhatikan oleh manajemen untuk dapat meningkatkan nilai perusahaan.

Berdasarkan hasil penelitian ini, terdapat pengaruh positif yang signifikan antara struktur modal terhadap nilai perusahaan. Artinya, semakin tinggi penggunaan hutang maka semakin tinggi pula nilai perusahaan. Perusahaan yang bertumbuh dengan baik dan memiliki peluang investasi yang besar di masa mendatang tentu memerlukan asupan dana yang besar pula, sehingga penggunaan hutang dari luar merupakan salah satu hal yang penting bagi perusahaan. Penggunaan hutang yang lebih besar juga menunjukkan tingkat kemampuan perusahaan dalam membayar hutangnya di masa depan atau dapat menunjukkan bahwa terdapat risiko bisnis yang rendah, sehingga hal itu direspon positif oleh investor yang dapat meningkatkan nilai perusahaan.

Hasil penelitian ini sejalan dengan Modigliani and Miller Theory yang menyatakan bahwa nilai perusahaan akan meningkat seiring dengan penggunaan hutang dengan asumsi adanya pajak karena besarnya biaya bunga hutang dapat dijadikan sebagai pengurang dalam pembayaran pajak. Selain itu, penelitian ini sejalan dengan hasil penelitian dari Hasania, dkk (2016) dan Manoppo dan Arie (2016) yang menyatakan hal yang sama, yaitu struktur modal berpengaruh positif signifikan terhadap nilai perusahaan. Namun, tidak sejalan dengan Manihuruk, et al. (2016) dan Syardiana, et al. (2015) yang menyatakan bahwa struktur modal tidak berpengaruh terhadap nilai perusahaan. 


\section{E. SIMPULAN DAN SARAN}

\section{Simpulan}

Hasil uji asumsi klasik diperoleh hasil uji nomalitas, uji multikolinearitas, uji autokorelasi, dan uji heteroskedastisitas yang menunjukkan tidak adanya variabel yang menyimpang dari asumsi klasik. Selain itu, berdasarkan uji faktor analisis diperoleh hasil bahwa semua variabel bebas dapat mewakili sebagai nilai struktur modal yang baru untuk mengetahui konsekuensi struktur modal terhadap nilai perusahaan. Kemudian, berdasarkan uji statistik t diketahui bahwa dalam model regresi 1 terdapat tiga variabel bebas yang terdukung, yaitu profitabilitas berpengaruh negatif signifikan, investment opportunity set berpengaruh positif signifikan dan kepemilikan manajerial berpengaruh negatif signifikan terhadap struktur modal. Sedangkan, dua variabel bebas lainnya dinyatakan tidak terdukung, antara lain ukuran perusahaan dan kebijakan dividen tidak berpengaruh terhadap struktur modal.

Kemudian, untuk model regresi 2 diketahui bahwa variabel struktur modal dinyatakan berpengaruh positif signifikan terhadap nilai perusahaan. Penelitian ini memberikan bukti empiris bahwa efek anteseden struktur modal terhadap nilai perusahaan adalah positif dan signifikan secara statistik.

\section{Saran}

Adapun saran-saran yang dapat diberikan peneliti sebagai berikut:

1. Investor atau kreditur sebaiknya dapat lebih cermat dalam pengambilan keputusan investasinya. Diharapkan hasil penelitian ini dapat digunakan sebagai salah satu sarana dalam pertimbangan pengambilan keputusan.

2. Peneliti selanjutnya diharapkan dapat memperluas sampel penelitian sehingga hasilnya dapat digeneralisir tidak hanya untuk perusahaan manufaktur. Peneliti selanjutnya diharapkan dapat membagi setting atau fokus perusahaan yang memiliki perbedaan tingkat tarif pajak yang dapat memengaruhi struktur modal.

\section{REFERENSI}

Ang, Robert. 1997. Buku Pintar Pasar Modal Indonesia (The Intelligent Guide to Indonesian Capital Market). Jakarta: Mediasoft Indonesia.

Angelya, Shelvy dan Erika Jimena Arilyn. 2017. Faktor-Faktor yang Mempengaruhi Struktur Modal pada Perusahaan Industri Makanan dan Minuman yang Terdaftar Dibursa Efek Indonesia. Jurnal Bisnis dan Akuntansi. Vol. 19 No. 1a. Issue 5, pp. 313-319.

Ashraf, Tanveer dan Rasool Safdar. 2013. Determinants of Leverage of Automobile Sector Firms Listed in Karachi Stock Exchange by Testing Pecking Order Theory. Journal of Business Studies Quarterly. Vol. 4 No. 3. pp. 73-83.

Atiqoh, Zummatul. 2016. Pengaruh Kinerja Keuangan, Size, Pertumbuhan Penjualan, dan Kepemilikan Saham terhadap Struktur Modal. Jurnal Ilmu dan Riset Akuntansi. Vol 5 No.5.

Babu, Suresh., dan G.V Chalam. 2014. Key Factors Influencing Capital Structure Decision of Indian Computer Software Industry. Indian Journal Of Applied Research. Vol. 4 No.6. pp103- 105.

Basil, Al-Najjar. 2011. The Inter-Relationship Between Capital Structure and Dividend Policy: Empirical Evidence from Jordanian Data. International Review of Applied Economics. Vol.25 No. 2. pp. 209-224.

Brealey, Richard A., Stewart C. Myers., and Franklin Allen. 2011. Principle of Corporate Finance, Tenth Edition. United States of America : New York, McGraw-Hill Irwin.

Binangkit, Bagas dan Sugeng Raharjo. 2014. Pengaruh Struktur Modal Terhadap Kinerja Perusahaan dan Harga Saham Pada Perusahaan Manufaktur di Bursa Efek Indonesia. Aktual edisi Pebruari 2014. Vol 1. No.2. pp. 24-34.

Brigham, E.F. dan J.F. Houston. 2006. Fundamentals of Financial Management. Tenth Edition. Cengange Learning Asia. Singapore. Terjemahan A.A. Yulianto. Dasar-dasar Manajemen Keuangan. Edisi Kesepuluh. Jilid dua. Jakarta: Salemba Empat.

Christiawan, Yulius Jogi dan Josua Tarigan. 2007. Kepemilikan Manajeral: Kebijakan Hutang, Kinerja dan Nilai Perusahaan. Jurnal Akuntansi dan Keuangan. Vol. 9 No. 1. pp. 1-8.

Cortez, Michael Angelo, dan Stevie Susanto. 2012. The Determinants Of Corporate Capital Structure: Evidence From Japanese Manufacturing Companies. Journal of International Business Research. Vol. 11 No.3. pp 121-134.

Darajati, Tuntun Sriwahyuni dan Deny Dwi Hartomo. 2015. Struktur Modal Sektor Perbankan Pada Saat Krisis 
Keuangan. Jurnal Bisnis \& Manajemen. Vol. 15 No. 1. pp 17-32.

Djumahir, 2005. Pengaruh Variabel-Variabel Tax Shield dan Non-Tax Shield Terhadap Struktur Modal dan Nilai

Perusahaan. Jurnal Wacana. Vol. 8 No. pp. 302-321

Fahmi, Irham. 2015. Pengantar Manajemen Keuangan. Edisi Ke-4. Bandung: Alfabeta.

Fitriyah, Fury K. dan Dina Hidayat. 2011. Pengaruh kepemilikan institusional, set kesempatan investasi dan arus kas bebas terhadap utang. Media Riset Akuntansi. Vol. 1 No. 1. pp. 31-42.

Fuad, Yanuar Cristie. 2015. Analisis Faktor-Faktor Yang Mempengaruhi Struktur Modal, Dengan Ukuran Perusahaan Sebagai Variabel Moderating. Diponegoro Journal of Accounting. Vol. 4 No. 2. pp 1-9.

Ghozali, Imam. 2016. Aplikasi Analisis Multivariete Dengan Program IBM SPSS 23 (Edisi 8). Cetakan ke VIII. Semarang : Badan Penerbit Universitas Diponegoro.

Hair, Joseph F, Black, William C, Babin Barry J and Anderson Rolph E. 2010. Multivariate Data Analysis A Global Perspective.Seventh Edition. Pearson.

Halim, Abdul. 2015. Manajemen Keuangan Bisnis: Konsep dan Aplikasinya, Edisi pertama. Jakarta: Mitra Wacana Media.

Hartono, Jogiyanto. 2015. Teori Portofolio dan Analisis Investasi Edisi Kesepuluh. Yogyakarta: BPFE.

Hasania, Zuhria, Sri Murni, dan Yunita Mandagie. 2016. Pengaruh Current Ratio, Ukuran Perusahaan, Struktur Modal, Dan Roe Terhadap Nilai Perusahaan Farmasi Yang Terdaftar Di Bursa Efek Indonesia Periode 2011 - 2014. Jurnal Berkala Ilmiah Efisiensi. Vol. 16 No. 03. pp. 133-144.

Hasnawati, Sri. 2005. Dampak Set Peluang Investasi Terhadap Nilai Perusahaan Publik di Bursa Efek Jakarta. JAAI. Vol. 9 No. 2. pp. 117-126.

Hastalona, Dyna.2013. Analisis Faktor-Faktor yang Mempengaruhi Kebijakan Hutang. Jurnal Keuangan dan Bisnis. Vol. 5 No.1.

Hidayah, Nurul. 2015. Pengaruh Investment Opportunity Set (IOS) dan Kepemilikan Manajerial Terhadap Nilai Perusahaan Pada Perusahaan Property dan Real Estate di Bursa Efek Indonesia. Jurnal Akuntansi. Vol. 19 No. 03. Pp. 420-432.

Hidayat, Riza., dan Sudarno. 2013. Analisis Faktor-Faktor Yang Mempengaruhi Struktur Modal Pada Perusahaan Manufaktur Terdaftar Di Bursa Efek Indonesia Periode 2007-2011. Diponegoro Journal Of Accounting. Vol. 2 No.2.

Himawan, Andreas dan Satriyo Wibowo. 2016. Pengaruh Non-Debt Tax Shield, Tangibilitas, Human Capital, Risiko Bisnis, Ukuran Perusahaan, Pertumbuhan, Likuditas Dan Profitabilitas Terhadap Financial Leverage Pada Sektor Komunikasi. Jurnal Bisnis dan Akuntansi. Vol. 18 No.2. pp. 217-226.

Husnan, Suad. 2013. Manajemen Keuangan Edisi Keempat. Yogyakarta: BPFE.

Indahningrum, Rizka Putri dan Ratih Handayani. 2009. Pengaruh Kepemilikan Manajerial, Kepemilikan Institusional, Dividen, Pertumbuhan Perusahaan, Free Cash Flow dan Profitabilitas terhadap Kebijakan Hutang. Jurnal Bisnis dan Akuntansi. Vol. 11 No. 3.pp. 189-207.

Jensen, Michael C. dan William H. Meckling. 1976. Theory of the Firm: Managerial Behavior, Agency Costs and Ownership Structure. Journal of Financial Economics. Vol. 3 No. 4. pp. 305-360.

Kasmir. 2016. Analisis Laporan Keuangan. Jakarta: Raja Grafindo Persada.

Larasati, Eva. 2011. Pengaruh Kepemilikan Manajerial, Kepemilikan Institusional dan Kebijakan Dividen terhadap Kebijakan Hutang Perusahaan. Jurnal Ekonomi Bisnis. Vol. 16 No. 2. pp 103-107.

Linda, Maya Febrianty Lautania, dan Muhammad Arfandynata. 2017. Determinan Kebijakan Hutang: Bukti Empiris pada Perusahaan yang Terdaftar di Bursa Efek Indonesia. Jurnal Dinamika Akuntansi dan Bisnis. Vol. 4 No. 1. pp 91-112.

M. Rustam. 2015. Penentuan Struktur Modal Optimal Pada Perusahaan Sektor Properti, Real Estate, dan Kontruksi yang Terdaftar di Bursa Efek Indonesia. Jurnal Ekonomi Bisnis dan Kewirausahaan. Vol. 4 No. 1. pp. 94124.

Manihuruk, Wiston, Djumahir, dan Sumiati. 2016. Determinants of Capital Structure and the Role of Capital Structure on Firm Value. European Journal of Business and Management. Vol. 8 No.26. pp. 182-194.

Manoppo, Heven dan Fitty Valdi Arie. 2016. Pengaruh Struktur Modal, Ukuran Perusahaan dan Profitabilitas Terhadap Nilai Perusahaan Otomotif Yang Terdaftar Di Bursa Efek Indonesia Periode 2011-2014. Jurnal Riset Ekonomi, Manajemen, Bisnis dan Akuntansi. Vol. 4 No.2. pp. 485-497.

Mardiyati, Umi, Qothrunnada, dan Destria Kurnianti. 2018. Pengaruh Kepemilikan Manajerial, Struktur Aktiva, Ukuran Perusahaan, Pertumbuhan Penjualan dan Profitabilitas Terhadap Kebijakan Utang Pada Perusahaan Sektor Aneka Industri Yang Terdaftar Di Bursa Efek Indonesia (BEI) Periode 2012-2016. Jurnal Riset Manajemen Sains Indonesia (JRMSI). Vol 9 No. 1. pp. 105-124.

Marfuah, Safitri Ana dan Siti Nurlaela. 2017. Pengaruh Ukuran Perusahaan, Pertumbuhan Asset, Profitabilitas Dan Pertumbuhan Penjualan Terhadap Struktur Modal Perusahaan Cosmetics And Household Di Bursa Efek Indonesia. Jurnal Akuntansi Dan Pajak. Vol. 18 No. 01. pp. 16-30.

Margaretha, Farah dan Aditya Rizky Ramadhan. 2010. Faktor-faktor yang Mempengaruhi Struktur Modal Pada 
Industri Manufaktur di Bursa Efek Indonesia. Jurnal Bisnis dan Akuntansi. Vol. 12 No. 2. pp. 119-130.

Maryanti, Eny. 2016. Analisis Profitabilitas, Pertumbuhan Perusahaan, Pertumbuhan Penjualan dan Struktur Aktiva

Terhadap Struktur Modal Pada Perusahaan Sektor Industri Barang Konsumsi Yang Terdaftar Di Bursa Efek Indonesia. Riset Akuntansi dan Keuangan Indonesia. Vol. 1 No. 2.

Mas'ud, Masdar. 2008. Analisis Faktor-Faktor Yang Mempengaruhi Struktur Modal dan Hubungannya Terhadap Nilai Perusahaan. Manajemen dan Bisnis. Vol. 7 No.1.

Masnoon, Maryam dan Abiha Saeed. 2014. Capital Structure Determinants of KSE Listed Automobile Companies. European Scientific Journal. Vol. 10 No. 13. pp 451-461.

Modigliani, Franco dan Merton H. Miller. 1958. The Cost of Capital, Corporate Finance, and the Theory of Investment. American Economics Review, 48, 261-297.

Murhadi. 2011. Analisis Laporan Keuangan, Proyeksi dan Valuasi Saham. Jakarta: Salemba Empat.

Myers, Stewart C. 1977. Determinants of Corporate Borrowing. Journal of Financial Economics. 5. 147- 175.

Myers, Stewart C. and Nicholas S. Maljuf. 1984. Corporate Financing and Invesment Decisions When Firms Have Information That Investor Do Not Have. Journal of Financial Economics. Vol. 13 No. 2. pp. 187-221.

Nurfina, Hida Efri dan Endang Tri Widyarti. 2016. Pengaruh Pengungkapan Corporate Social Responsibility, Kebijakan Dividen, Profitabilitas, Struktur Modal, Dan Ukuran Perusahaan Terhadap Nilai Perusahaan. Diponegoro Journal of Management. Vol. 5 No. 3. pp. 1-10.

Ramli, Moh. Rusman dan Frans Papilaya. 2015. Pengaruh Investment Opportunity Set Terhadap Struktur Modal Perusahaan. Jurnal Keuangan dan Perbankan. Vol. 12 No.3. pp. $411-420$.

Rely, Gilbert dan Dr. Herry Sunarto. 2017. Determinants of Capital Structure Journal on Business Review. Vol. 5 No. 2.

Riyadi, Syamsul. 2018. Analisis Nilai Perusahaan pada Perusahaan Manufaktur. Jurnal Sinar Manajemen. Vol. 5 No. 1. pp. 38-43.

Riyanto, Bambang. 2010. Dasar-Dasar Pembelajaran Perusahan. Yogyakarta: BPFE Universitas Gadjah Mada.

Rodoni, Ahmad dan Herni Ali. 2010. Manajemen Keuangan. Jakarta: Mitra Wacana Media.

Rumondor, Regina, Maryam Mangantar, dan Jacky S.B. Sumarauw. 2015. Pengaruh Struktur Modal, Ukuran Perusahaan dan Risiko Perusahaan Terhadap Nilai Perusahaan Pada Sub Sektor Plastik Dan Pengemasan Di BEI. Jurnal Riset Ekonomi, Manajemen, Bisnis dan Akuntansi. Vol. 3 No.3. pp. 159-169.

Rustam, M. 2015. Penentuan Struktur Modal Optimal Pada Perusahaan Sektor Properti, Real Estate, dan Kontruksi yang Terdaftar di Bursa Efek Indonesia. Jurnal Ekonomi Bisnis dan Kewirausahaan. Vol. 4 No. 01. pp 94124.

Sari, Dessy, Handa., Atim, Djazuli., dan Siti Aisjah. 2013. Determinan Struktur Modal dan Dampaknya terhadap Nilai Perusahaan (Studi pada Perusahaan Makanan dan Minuman di Bursa Efek Indonesia). Jurnal Aplikasi Manajemen. Vol. 11 No. 1. pp 77-84.

Sari, Nurshadrina Kartika, Isti Fadah, dan Hari Sukarno. 2012. Determinan Struktur Modal Bank. Jurnal Ekonomi dan Keuangan. Vol. 17 No. 1. pp $71-88$.

Sartono, Agus. 2010. Manajemen Keuangan; Aplikasi dan Teori. Yogyakarta: BPFE.

Savitri, Enni, Ubud Salim, Armanu, dan Djumahir. 2012. Variabel Anteseden dari Struktur Modal: Dampaknya Terhadap Nilai Perusahaan. Jurnal Aplikasi Manajemen. Vol. 10 No.1. pp. 85-96.

Sheikh, Nadeem Ahmed dan Muhammad Azeem Qureshi. 2017. Determinants of capital structure of Islamic and conventional commercial banks: Evidence from Pakistan. International Journal of Islamic and Middle Eastern Finance and Management. Vol. 10. No.1. pp.24-41.

Sheikh, Nadeem Ahmed dan Zongjun Wang. 2011. Determinants of capital structure An empirical study of firms in manufacturing industry of Pakistan. Managerial Finance. Vol. 37 No.2. pp.117-133.

Sheisarvian, Revi Maretta, Nengah Sudjana, dan Muhammad Saifi. 2015. Pengaruh Kepemilikan Manajerial, Kebijakan Dividen dan Profitabilitas Terhadap Kebijakan Hutang. Vol.22 No.1. pp. 1-9.

Situmorang, Syafrizal Helmi dan Muslich Lutfi. 2011. Analisis Data Untuk Riset Manajemen dan Bisnis, Edisi 2. Medan: USU Press.

Smart, S.B., W.L. Megginson and L.J .Gitman. 2004. Corporate Finance. 2nd Edition. Mason: Thomson

Sofat, Rajni dan Sukhdev Singh. 2017. Determinants of capital structure: an empirical study of manufacturing firms in India. International Journal of Law and Management. Vol. 59. Issue: 6. pp.1029-1045.

Sofilda, Eleonora dan Maryani. 2007. Analisa Faktor Penentu Stuktur Modal Perbankan di Indonesia. Media Riset Akuntansi, Auditing dan Informasi. Vol. 7 No.3. pp. 351-366.

Soleman, Rusman. 2008. Karakteristik Perusahaan Terhadap Tingkat Leverage. Jurnal Keuangan dan Perbankan. Vol.12 No.3. pp. $411-420$.

Sugiyono. 2017. Metode Penelitian Kuantitatif, Kualitatif, dan R\&D. Bandung: Alfabeta.

Suliyanto, 2005. Analisis Data Dalam Aplikasi Pemasaran. Bogor: Ghalia Indonesia.

Suryani, Ade Dwi dan Muhammad Khafid. 2015. Pengaruh Free Cash Flow, Pertumbuhan Perusahaan, Kebijakan Deviden dan Ukuran Perusahaan Terhadap Kebijakan Hutang pada Perusahaan Manufaktur di Bursa Efek 
Indonesia Tahun 2013. Dinamika Akuntansi, Keuangan dan Perbankan. Vol. 4 No. 1. pp. 20- 28.

Susanto, Yulius Kurnia. 2011. Kepemilikan Saham, Kebijakan Deviden, Karakteristik Perusahaan, Risiko Sistimatik,

Set Peluang Investasi dan Kebijakan Hutang. Jurnal Bisnis dan Akuntansi. Vol. 13 No. 3. pp. 195-210.

Syardiana, Gita, Ahmad Rodoni, dan Zuwesty Eka Putri. 2015. Pengaruh Invesment Opportunity Set, Struktur

Modal, Pertumbuhan Perusahaan, dan Return on Asset Terhadap Nilai Perusahaan. Akuntabilitas. Vol. 8

No.1. pp 39-46

Tamam, Dede Badru dan Satriyo Wibowo. 2017. Pengaruh Tangibility, Profitability, Liquidity, Firm Size, dan Non

Debt Tax Shield Terhadap Capital Structure Pada Sektor Pertanian. Jurnal Bisnis dan Akuntansi. Vol. 19 No. 1. pp 129-135.

Tangiduk, Desmianti, Paulina Van Rate, dan Johan Tumiwa. 2017. Analisis Pengaruh Ukuran Perusahaan, Struktur Aktiva, Dan Profitabilitas Terhadap Struktur Modal Pada Perusahaan Manufaktur Sektor Industri Dasar Dan

Kimia Yang Terdaftar Di Bursa Efek Indonesia Periode 2011-2015. Jurnal EMBA. Vol. 5 No.2. pp 874-883.

Titman, S., dan Wessels, R. 1988. The Determinant of Capital Structure Choise. Journal of Finance. Vol. 43 No.1. pp. 106-131.

Weston, J. Fred dan Copeland, Thomas E. 1997. Manajemen Keuangan Edisi 9. Jakarta Barat: Binarupa Aksara. Widarjono, Agus. 2013. Ekonometrika Pengantar dan Aplikasinya, Edisi Keempat. Yogyakarta : UPP STIM YKPN. Wimelda, Linda, dan Aan Marlinah. 2013. Variabel-Variabel yang Mempengaruhi Struktur Modal Pada Perusahaan Sektor Non Keuangan. Media Bisnis. Vol. 5 No. 3. pp. 200-213.

\section{Lampiran 1}

Daftar Sampel Perusahaan Manufaktur

\begin{tabular}{|c|c|c|}
\hline No. & Nama Perusahaan & Kode \\
\hline 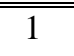 & PT AKASHA WIRA INTERNATIONAL Tbk & ADES \\
\hline 2 & PT ARGHA KARYAPRIMAINDUSTRY Tbk & AKPI \\
\hline 3 & PT ALKINDO NARATAMA Tbk & ALDO \\
\hline 4 & PT ASAHIMAS FLAT GLASS Tbk & AMFG \\
\hline 5 & PT ASTRA INTERNATIONAL Tbk & ASII \\
\hline 6 & PT ASTRA OTOPARTS Tbk & AUTO \\
\hline 7 & PT SEPATU BATA Tbk & BATA \\
\hline 8 & PT BUDI STARCH \& SWEETENER Tbk & BUDI \\
\hline 9 & PT WILMAR CAHAYA INDONESIA Tbk & CEKA \\
\hline 10 & PT CHAROEN POKPHAND INDONESIA Tbk & CPIN \\
\hline 11 & PT DELTA DJAKARTA Tbk & DLTA \\
\hline 12 & PT DARYA-VARIA LABORATORIA Tbk & DVLA \\
\hline 13 & PT GUDANG GARAM Tbk & GGRM \\
\hline 14 & PT HANJAYA MANDALA SAMPOERNA Tbk. & HMSP \\
\hline 15 & PT CHAMPION PACIFIC INDONESIA Tbk & IGAR \\
\hline 16 & PT INDAL ALUMINIUM INDUSTRY Tbk & INAI \\
\hline 17 & PT INTANWIJAYA INTERNASIONAL Tbk & INCI \\
\hline 18 & PT INDOCEMENT TUNGGAL PRAKARSA Tbk & INTP \\
\hline 19 & PT JAPFA COMFEED INDONESIA Tbk & JPFA \\
\hline 20 & PT KIMIA FARMA (Persero) Tbk & KAEF \\
\hline 21 & PT KEDAWUNG SETIA INDUSTRIALTbk & KDSI \\
\hline 22 & PT KALBE FARMA Tbk & KLBF \\
\hline 23 & PT LION METAL WORKS Tbk & LION \\
\hline 24 & PT LIONMESH PRIMA Tbk & LMSH \\
\hline 25 & PT. NIPRESS Tbk & NIPS \\
\hline 26 & PT PELANGI INDAH CANINDO Tbk & PICO \\
\hline
\end{tabular}




\begin{tabular}{clc}
\hline No. & \multicolumn{1}{c}{ Nama Perusahaan } & Kode \\
\hline \hline 27 & PT RICKY PUTRA GLOBALINDO Tbk & RICY \\
28 & PT NIPPON INDOSARI CORPINDO Tbk & ROTI \\
29 & PT SUPREME CABLE MANUFACTURING \& COMMERCE Tbk & SCCO \\
30 & PT SEKAR BUMI Tbk & SKBM \\
31 & PT SEKAR LAUT Tbk & SKLT \\
32 & PT SELAMAT SEMPURNA Tbk & SMSM \\
33 & PT INDO ACIDATAMA Tbk & SRSN \\
34 & PT SIANTAR TOP Tbk & STTP \\
35 & PT MANDOM INDONESIA Tbk & TCID \\
36 & PT SURYA TOTO INDONESIA Tbk & TOTO \\
37 & PT Trias Sentosa Tbk & TRST \\
38 & PT ULTRAJAYA MILK INDUSTRY \& TRADING COMPANY Tbk & ULTJ \\
39 & PT. NUSANTARA INTI CORPORA Tbk & UNIT \\
40 & PT UNILEVER INDONESIA Tbk & UNVR \\
41 & PT WISMILAK INTI MAKMUR Tbk & WIIM \\
\hline \hline
\end{tabular}

